\title{
MOUTINHO, José Viale. Histórias do Tempo da Outra Senhora. Lisboa: Esfera do Caos, 1985, 94 p.
}

Denis Leandro Francisco Universidade Federal de Minas Gerais

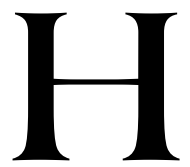

istórias clandestinas, dramáticas, de luta e resistência: os 16 contos poéticos - ou poemas em prosa que conformam essas Histórias do Tempo da Outra Senhora demonstram um trabalho de invenção formal, de experimentação com a palavra e, ao mesmo tempo, de tratamento de elementos grotescos que se apresentam sob um viés ora macabro, ora satírico.

O narrador-poeta de José Viale Moutinho faz seu acerto de contas com um certo período da história portuguesa - quem será essa "outra senhora" senão aquela que atende pelo nome de ditadura ou tirania? - e, para levar a cabo sua empreitada, não apenas rememora, ficcionalmente, o passado, mas o presentifica e o atualiza numa estrutura narrativa invulgar: à enunciação pode ser atribuída uma temporalidade que é, quase sempre, de passado, mas que, no avançar de cada conto, gradativamente assume um caráter de atualidade, passando a explorar o tempo da própria linguagem, como se a prosa intentasse, por esse artifício, ingressar na atemporalidade $\mathrm{da}$ poesia ou como se o passado opressor, para se expurgar, quisesse - ou tivesse que - fazer-se atual.

A história, a luta de classes, a violência e opressão políticas estão presentes, de forma bem marcada, 
em todos esses textos. $\mathrm{O}$ primeiro deles - "Como medo" - já anuncia, em seu título, a sombra de uma PIDE - a polícia política portuguesa - que não cessa de espalhar horror, medo e morte pelas ruas portuguesas:

é comigo

depois não

afastam-se

fico estendido de bruços, o rosto no cimento

\section{(...)}

o cimento aquece debaixo do meu rosto,

uma pancada na nuca e pronto. ${ }^{1}$

O derradeiro conto - "Os heróis" - sugere uma (falsa) idéia de redenção: esses "heróis" são jovens que, satisfeitos com a notícia de que haveria vagas de trabalho nas fábricas do país vizinho, são recrutados como operários para, ao final, descobrirem-se ludibriados e forçados a servirem na guerra espanhola contra a força roja. Os enganados encontram aí o seu fim, sem retorno ou escapatória, sem socorro ou indulgência: um oficial deu um tiro na cabeça de um dos rapazes que estavam a marcar passo e disse que aquele era o fim de quem se atrevesse a refilar (...). ${ }^{2}$

Jogando com o onírico - "O rebanho de vidro" - e o grotesco "Caçada nocturna" -, o autor delineia sua breve mitologia do horror, que pode ter como motivação ficcional a violência, a política, a loucura ou a morte. Valendo-se de uma linguagem ágil e ela própria esfacelada, com vocábulos sempre cortados ao meio e por uma sintaxe truncada e compactada até o limite do verso, a escrita de José Viale Moutinho intenta, em sua forma, elaborar uma denúncia contra a opressão e a estrangulação dos direitos de liberdade.

A despeito da atmosfera lúgubre, que envolve esse conjunto de textos, em pelo menos dois deles, se pode entrever algum sinal de esperança quanto ao futuro do homem, em meio à difícil construção de sua história. Em "Maçãs na cela", a solidariedade dá

\footnotetext{
MOUTINHO, p. 13-14.

${ }^{2}$ MOUTINHO, p. 13-14.
} 
mostras de uma luminosidade, que se faz possível até no mais obscuro dos cárceres e, no conto de abertura, em nítido contraste com o seu título infausto, percebe-se a continuidade de uma resistência em favor da liberdade:

nesta mesma praça onde de bruços suportei

o chão

e as botas dos polícias provocaram o medo

há-de erguer-se uma estátua do tempo

com as algemas quebradas,

em nome das pequenas eternidades, e com um verso de Aragon como legenda:

sonhavas com ser livre e eu te continuo. ${ }^{3}$

O calcanhar-de-aquiles da obra fica por conta do seu projeto editorial: uma apresentação adequada do autor e sua devida contextualização, no panorama da literatura portuguesa contemporânea, fazem imensa falta para uma leitura mais bem situada de um livro tão atravessado por questôes histórico-contextuais. O texto de José Viale Moutinho merecia o esforço.

${ }^{3}$ MOUTINHO, p. 20. 